УДК: 7.034:002.2

ББК: $85.103(4) 5 ; 85.157 ; 85.126 .8$

A43

DOI: $10.18688 / \mathrm{aa} 177-10-70$

Rosamund Oates, Nina Adamova, Vladimir Baryshnikov

\title{
Research project "Communities of Print in Early Modern Europe”
}

Over the last few decades, art history has been growing into a multidisciplinary field of research. One of its dimensions is visual culture studies ${ }^{1}$, which bring art history together with anthropology, social history, philosophy, psychology, geography and other disciplines. This approach extends the understanding of the objects of art by embedding them into contemporary outlook and practices. Regarding Renaissance Europe, the perspective of visual culture complements existing knowledge by including social, visual, economic dimensions of art in the whole picture. Such an approach seems to be especially valuable for this period, as the early modern Europe experienced a tremendous expansion of visual objects and constant change of the patterns of viewership. These changes developed new attitudes and practices of perceiving and using the objects of art and preconditioned the early mass production of these objects ${ }^{2}$.

The printing press was one of these significant Renaissance innovations. It gave an impetus for the multiplication and dissemination of the books as the visual culture objects. Early modern books were not just a medium to reproduce the text, they also functioned as a commodity in domestic and international trade. They were also an object to collect, a product of a craft involving skilful artisans and artists. Books created communities of producers, owners, and readers; they increased the flow of texts in vernacular, sometimes across social, national and cultural borders [5, p.1]. Books often included illustrations with their own aesthetical value, which sometimes influenced other types of applied arts, for example, painting, carving, and embroidery [3, p. 80; 7]. There were, however, limits to this "printing revolution". The printing press did not eradicate handwritten manuscripts, and for a long time printed books coexisted with the manuscript culture. Furthermore, printed texts could not replace traditional oral and visual media [3, pp.78-79; 5, pp. 97-121].

There was a powerful tension at the heart of early modern print culture. While the new printing presses allowed the creation of hundreds of uniform copies of different texts, in reality by the time those texts had been bound, bought and read each book became a unique artefact. Readers wrote in the margins or paid for expensive or cheap binding. Sometimes booksellers bound different texts together, creating unexpected (and unique) versions of the original works. Readers were also writers, annotating and changing their books in light of their unique experiences of life and their own reading patterns. So, in the face of mass production, the book

1 For visual culture studies, see: [4]; for changes in the art history and its connection to the studies in material culture, see: [6, pp.3-28].

2 For implementations of this approach, see, for example Svetlana Alpers' book on the Renaissance Dutch visual culture [1] and George R. Bent's study of public painting in Florence [2]. 
reasserted its individuality through its existence as an artefact as well as a carrier of ideas. Nowadays, a scholar can hardly find two identical copies of early modern books, and annotations, the marks of ownership, irrelevant writings, and other evidence can tell us a lot about circulation of the books and the practices of readership [5, p. 447].

These and other features of early modern books as the objects of visual culture and social history are investigated in the research project under the review - "Communities of Print: Using Books in Early Modern Europe”. The project was initiated and launched by Dr Rosamund Oates (Manchester Metropolitan University, UK) in 2016. Dr Oates founded an international network of scholars specializing in art, history and literary studies, as well as librarians and archivists working on various aspects of early modern printing culture. "Communities of Print" project focuses on the visual and social impact of the books, the role of the books in creating communities, and their usage in communal settings. These challenging tasks imply a number of questions: how were the books read - silently, aloud, alone or in the company? What were reactions of the readers to what they read? Who could afford to buy books or how could they access them? Who could use the private libraries? How were the books used (some owners could put irrelevant notes in the books, very often - recipes, some kept sacred books just for their "magical qualities" [3, p. 85])? What was interrelation between using the books and manuscripts? The project also involves another important practical topic: what implications all this has for recording and displaying (digitising?) old books?

The first meeting organised within the scope of the Project was a two-day conference Communities of Print: Using Books in Early modern Europe in June 2016 ${ }^{3}$. It investigated two related questions: how books created communities of readers, and what were the implications of this work for practitioners who store, catalogue and exhibit annotated rare books.

The first day of the conference consisted of papers and discussions by the Community of Print network - a small group of invited scholars. This was based at John Rylands Library, Deansgate Manchester and Manchester Metropolitan University. Papers included Flavia Bruni (University of Rome), who discussed collective reading practices and the use of "et amicorum" by Friars in Renaissance Italy, basing on her in-depth study of Italian monastic libraries. Rosamund Oates (Manchester Metropolitan University) explored similar practices in early modern England, asking how "private" readers' marks were. Through investigation of book annotations in the library of an archbishop of York, Tobias Matthew, Rosamund Oates illustrated some patterns of his reading habits. Julianne Simpson (John Ryland's Library) reconstructed the trade networks of one of the most influential $16^{\text {th }}$-century publishers and printers, Christopher Plantin. In her meticulous research, Julianne Simpson traced the European dissemination of Plantin's most ambitious project - the Polyglot Bible. Nina Adamova (Saint Petersburg State University) examined the biblical references and specific tropes used in the printed texts produced by $17^{\text {th }}$-century British settlers in America and showed how they created a Protestant "pilgrim identity" in print. Adam Morton (University of Newcastle), in his paper Kissing the Pope's Toe: Community and Contestation through Reformation Polemic explored the evolution of anti-Catholicism in early modern Protestant print through the use of the image of "kissing the Pope's toe".

3 Some of the conference material is already available at the blog of the Project website: https://communitiesofprint.wordpress.com/ (accessed 10 July 2017). 
The second day was open to the wider academic community. The whole day was based at Chetham's Library, Manchester. Network members gave papers in the morning, while postgraduate students gave shorter presentations in the afternoon. Such a schedule provided an opportunity for postgraduate and early career researchers to interact with more senior colleagues, and to explore the "practical" implications of their research for archivists and librarians.

Researchers explored the transition from manuscript to print cultures and from medieval to early modern. Sabrina Corbellini (University of Groningen) in her presentation New Communities of Readers in Late Medieval and Early Modern Italy discussed findings from two international projects she co-ordinates on the history of reading. Using Venetian sources, she showed that the cultural capital of books extended far beyond a literate elite. Matthew Fisher (University of California, Los Angeles) and Kathryn Hurlock (Manchester Metropolitan University) both explored how $16^{\text {th }}$-century readers appropriated medieval texts. In his paper Medieval Manuscripts and Early Modern Readers, Matthew Fisher examined the manuscript collections of early modern antiquary Peter Manwood. Kathryn Hurlock looked at different annotated copies of David Powell's Historie of Wales (1584) in her paper Medieval Wales in the Early Modern Imagination. In the afternoon, postgraduate and early career researchers presented their findings on the theme of print, communities, and visual culture: a rich and varied series of papers addressing spelling in $15^{\text {th }}$-century print; vampires in the early modern imagination; the black death in medieval chronicles; and Elizabethan depictions of the Americas.

Both days included a hands-on element and discussions about how to catalogue and exhibit annotated books. At John Rylands, Julianne Simpson provided some examples of annotated books and addressed digitisation projects. At Chetham's Library, Michael Powell and Fergus Wilde led a discussion about curating rare books and showed some of the library's treasures. Librarians spoke about important characteristics of the books as visual and physical objects: smell, actual size, tangibility of a surface, and other physical details, which are often important for a researcher but cannot be reproduced digitally.

By bringing together a network of scholars, practitioners and graduate students, including specialists in English literature, history, art and archival studies, this conference laid a foundation for the development of the project "Communities of Print". On the whole, the papers presented by the participants of the conference demonstrated the various dimensions of early modern books as physical and visual objects, commodity and property, as a source of imagination and as a characteristic feature of Renaissance visual culture and art.

\section{References}

1. Alpers S. The Art of Describing: Dutch Art in the Seventeenth Century. Chicago, University of Chicago Press, 1983. $273 \mathrm{p}$.

2. Barnard J.; McKenzie D. F.; Bell M. (eds.). The Cambridge History of the Book in Britain. Vol.4. 1557-1695. Cambridge, Cambridge University Press, 2002. 855 p.

3. Bent G. R. Public Painting and Visual Culture in Early Republican Florence. New York, Cambridge University Press, 2016. 334 p.

4. Green I. Print. Understanding Early Modern Sources. L. Sangha; J. Willis (eds.). London; New York, Routledge Publ., 2016, pp. 78-94.

5. Richardson C.; Hamling T.; Gaimster D. (eds.). The Routledge Handbook of Material Culture in Early Modern Europe. London; New York, Routledge Publ., 2017. 506 p.

6. Smith M. Visual Culture Studies: Questions of History, Theory and Practice. The Art of Art History: A Critical Anthology. D. Preziosi (ed.). New York, Oxford University Press, 2009, pp. 455-467. 
7. Wells-Cole A. Art and Decoration in Elizabethan and Jacobean England: The Influence of Continental Prints, 1558-1625. New Haven; London, Yale University Press, 1997. 344 p.

Title. Research Project "Communities of Print in Early Modern Europe".

Authors. Rosamund Oates - Ph. D., senior lecturer. Manchester Metropolitan University, Geoffrey Manton Building, Rosamond St. West, Manchester, United Kingdom, M15 6LL.r.oates@mmu.ac.uk

Adamova, Nina Eduardovna - Ph. D., head lecturer. Saint Petersburg State University, Universitetskaia nab., 7/9, 199034 St. Petersburg, Russian Federation.n.adamova@spbu.ru

Baryshnikov, Vladimir Nikolaevich - full doctor, professor, head of the Modern History chair. Saint Petersburg State University, Universitetskaia nab., 7/9, 199034 St. Petersburg, Russian Federation. v.baryshnikov@ spbu.ru

Abstract. The paper discusses the international multidisciplinary research project "Communities of Print: Using Books in Early Modern Europe", launched by Manchester Metropolitan University (UK) in 2016. The project united the leading scholars specialising in art history, early modern history and literary studies, as well as librarians and archivists. The project "Communities of Print" explores early modern books not just as a medium for distributing information, but as material objects of Renaissance visual culture and art. It focuses on the visual and social impact of the books on various communities and examines their usage in communal settings. The paper also briefly outlines the presentations made at the first conference organised within the project in June 2016 in Manchester. They concerned such topics as the public availability of monastic and private libraries in early modern culture, book trading networks in Europe, the attribution of ownership marks and annotations, usage of medieval manuscripts and their role in early modern book collections, reading practices and access to printed material, and the evolution of anti-Catholic imagery in the early modern Protestant print. Finally, the paper observes some implications of the project, which stem from the close cooperation of researchers of art, history, literature and practitioners - librarians and archivists, - such as refining the knowledge and understanding of early modern books as the objects of visual culture.

Keywords: rare books; print; early modern books; early modern libraries; visual culture; reading practices; book trade; Renaissance; manuscripts.

Название статьи. Исследовательский проект «Книжные сообщества в Европе раннего Нового времени».

Сведения об авторах. Оатс Розамунд - Ph. D., старший преподаватель. Университет Манчестер Метрополитен, Джеофри Ментон Билдинг, Розамонд Сент-Вест, Манчестер, Великобритания, M156LL.r.oates@mmu.ac.uk

Адамова Нина Эдуардовна - кандидат исторических наук, старший преподаватель. Санкт-Петербургский государственный университет, Университетская наб., д. 7/9, Санкт-Петербург, Российская Федерация, 199034.n.adamova@spbu.ru

Барышников Владимир Николаевич - доктор исторических наук, профессор, заведующий кафедрой Новой и Новейшей истории. Санкт-Петербургский государственный университет, Университетская наб., д.7/9, Санкт-Петербург, Российская Федерация, 199034. v.baryshnikov@spbu.ru

Аннотация. В статье дается краткий обзор международного междисциплинарного научного проекта «Книжные сообщества: использование книг в Европе раннего Нового времени», организованного Университетом Манчестер Метрополитен (Великобритания) в 2016 г. Данный проект объединил ведущих исследователей в области истории искусства, истории и литературы раннего нового времени, библиотекарей и архивистов. Цель проекта «Книжные сообщества» - исследовать книги раннего нового времени не в качестве носителей информации, а как материальные объекты визуальной культуры и искусства данной эпохи. Внимание участников проекта сосредоточено на визуальном и социальном воздействии книг на различные сообщества, а также на коллективных практиках использования книг раннего нового времени. Кроме того, в статье дается краткий обзор докладов, представленных на первой конференции, проведенной в рамках данного проекта в июне 2016 г. в Манчестере. В докладах обсуждались такие темы, как общественная доступность монастырских и частных библиотек в раннее Новое время, схемы книжной торговли в Европе, вопросы атрибуции аннотаций и отметок владельцев, роль средневековых рукописей в собраниях коллекционеров раннего Нового времени, практики чтения и вопросы доступа к печатным материалам, а также особенности эволюции антикатолических изображений в протестантской печати. Наконец, в статье рассказывается о результатах, которые принесет проекту тесное сотрудничество искусствоведов, историков и литературоведов с практиками - библиотекарями и архивистами, - в частности, углубление нашего понимания книг раннего Нового времени как объектов визуальной культуры.

Ключевые слова: редкие книги; печать; книги; библиотеки раннего Нового времени; визуальная культура; практики чтения; книжная торговля; Ренессанс; рукописи. 